\title{
Determining Factors of the Development of A National Financial Center: the Case of China*
}

\author{
Dr. Simon X.B. Zhao, Department of Geography and International Centre for China \\ Development Studies, The University of Hong Kong \\ Dr. Li Zhang, Department of Geography and Resource Management, The Chinese University \\ of Hong Kong \\ Mr. Danny T. Wang, Department of Geography, The University of Hong Kong
}

\begin{abstract}
This study explores, theoretically and empirically, one of the important issues of the geography of finance: the location of high-level financial services. Specifically, we will try to explain why foreign financial services are spatially concentrated on a particular city to form a national financial center in China. By reviewing various forces behind the formation of a financial center, we argue that information problems have created the necessity of the geographic agglomeration of financial activities in the source of information even in the era when financial markets have worked through sophisticated telecommunication networks. Based on the survey of the actual location of MNC regional headquarters and reasons of the headquarters agglomeration, we anticipate that Beijing, as the prime source of policy information, is more advantageous than other Chinese cities to be the national number one financial center when the Chinese financial markets become more open to foreign firms in the near future. Thus, this study illustrates, using China as a case, that geography still provides major justification of why major financial services continue to have a high degree of spatial agglomeration in particular locations, despite electronic transmission of information has substantially reduced the friction of distance.
\end{abstract}

\footnotetext{
* A partial result of this paper was presented at the $29^{\text {th }}$ International Geographical Congress, Seoul, Korea in 13-17 August 2000 and at the Annual Meeting of the Chinese Economic Society (USA), Hong Kong in 27-28 June 2002. We would like to thank Prof. Christopher J. Smith and many individuals from China Securities Regulatory Commission, China Insurance Regulatory Commissions, China International Capital Corporation, China's Construction Bank and Morgan Stanley Dean Witter, for their valuable comments and technical assistances. Special gratitude is due to the Lotus Trade Center for its invaluable help in assembling materials and in charge of the survey of foreign head-offices. The authors would like to acknowledge financial supports from The University of Hong Kong. Many thanks also go to our research assistant, Miss Yvonne L.Y. Hung, for her assistance in collecting and processing the data.
} 


\section{Introduction}

Innovations of telecommunication and information technologies have brought about a fast and efficient global transmission of goods, capital and information. In the context of globalization accelerated by technological progresses, the location choice of firms seems becoming footloose. Many scholars believe that the economic role of space is increasingly insignificant. Castells (1989) asserts that, with sophisticated networks of electronic communications and electronic money, the circulation of capital is no longer obstructed by distance. O’Brien (1992) perceives the "end of geography", in the sense that location is no more a determining factor for business. Cairncross (1997) declares the "death of distance". Ohmae (1990, 1995a, 1995b) and Kobrin (1997) argue that the power of globalization has overridden the sovereignty and autonomy of nation-states, making the economic space of a country meaningless.

However, Berry et al (1997) argue that, to firms with particular functions, spatial proximity is still critical, since not all types of information can be transmitted over distance with constant costs. Martin (1994) points out that some arguments about the spatial effects of globalization generally ignore the dialectic nature of globalization, which involves the tension between the divergent forces of dispersion and agglomeration. The effects of path dependence and asymmetric information can reinforce the concentration of businesses around specific centers. Sassen (1995) and Short \& Kim (1999) find that the headquarters of multinational corporations (MNCs) tend to be concentrated on world cities. This school of thought claims that geographic proximity is still essential to businesses.

The development of financial centers offers a good example to illustrate the continuous significance of geography in the location choice of businesses. By exemplifying the case of London, Thrift (1994) explores that international financial centers have a particular set of locational determinants. He argues that the local characteristics and localized 
information jointly define the advantages of a given location as a financial center. Porteous (1995, 1999) suggests that the agglomeration process of financial services can be understood by assessing the importance of information hinterland and asymmetric information. Martin (1999) asserts that the friction of information flows across physical distance affects the location of financial activities, as information collection and verification are particularly crucial for financial business to play safe games. Leyshon $(1995,1997)$ compressively summarizes the state of arts of Geography of money and finance, and emphasizes the political economic approach to the discipline. He argues that "enduring salience of the political economic approach in understanding the formation of geographies of money and finance.” He also puts forth the idea that it is important to "consider the influence of a wide range of social and, in particular, cultural factors which might contribute to the success and survival of international financial center” (Leyshon, 1997). He also suggests numerous ways in which political economic approach in understanding the dynamic of a fast moving and increasingly powerful financial system (for details, see Leyshon 1995, 1997).

As a country undergoing systemic reforms, China will soon open its financial markets more widely to the outside world than ever before. With recent accession to the WTO, China has promised to further release the limitations for foreign financial firms on the market access, as well as on the geographic coverage of their business (Ministry of Foreign Trades and Economic Cooperation, 2002). Foreign financial firms are allowed to enter into previously monopolized markets. For example, upon accession, foreign life insurers will be permitted to have 50 per cent foreign ownership in a joint venture with the partner of their choices. Within two years after China's accession, there will be no form of restrictions for the establishment of foreign non-life insurers. Foreign non-life insurers will be permitted to provide the full range of non-life insurance services to both foreign and domestic clients with no geographic restrictions. For foreign currency business, there will be no geographic restrictions upon accession and foreign financial institutions will be permitted to provide services in China 
without restriction as to clients. Within five years, all geographic restrictions on local currency business will be removed. Under certain conditions, foreign financial institutions are permitted to establish a subsidiary of a foreign bank or a foreign finance company in China. Foreign securities institutions may engage directly (without Chinese intermediary) in B share business. With such great release of institutional restrictions, it is expected that more and more foreign financial firms will provide business and services in the Chinese market and that financial centers with international attachment would be formed in some Chinese cities.

In this context, this paper will try to explain why foreign financial services are spatially concentrated on a particular city to form a national financial center in China. By reviewing various forces behind the formation of a financial center, we argue that information problems have created the necessity of the geographic agglomeration of financial activities in the source of information even in the era when financial markets have worked through sophisticated telecommunication networks. Thus, this study illustrates, using China as a case, that geography still provides major justification of why the financial sector has its high degree of spatial agglomeration in particular locations, despite electronic transmission of information has substantially reduced the friction of distance.

The paper is organized as follows. The next section reviews the determining factors of a financial center underlined in the extant literature of financial geography. Some ideas which emerge from the review are put forward for empirical test. Section 3 discusses the methodological issues encountered in this research. Section 4 investigates and explains the location choice of MNC regional headquarters in China, which arguably is a key indicator of the formation of a financial center. Some conclusions are drawn in the final section. 


\section{The Theoretical Basis: Factors Determining the Development of}

\section{Financial Centers}

To understand the development of financial centers, we are particularly concerned with three interrelated questions. How can a financial center be identified? Why is there spatial agglomeration of financial activities? Why are financial activities spatially concentrated in a selected location? A financial center is conventionally regarded as a place with the agglomeration of financial institutions providing all banking and financial services nationally or internationally. Financial centers can be classified, in terms of geographic influence, as national, regional, zonal, or global centers (Daly, 1984). Several measures, as Kerr (1965), Park \& Essayyad (1989), and Porteous (1999) suggested, can be used to identify specific cities which have functioned as financial centers. These measures include employment in the financial sector relative to the total employment, assets of financial institutions, the proportion of cheques cashed, the turnover value of stock exchange, the volume of communications (especially express mails and telecommunications), and the presence of foreign banks and head-offices of large multinational non-financial corporations. Depending on the availability of data, these measures can be assembled into a composite Financial Center Index (FINDEX), which quantifies the significance of a financial sector in the city (Kerr, 1965; Porteous, 1995).

In a broader sense, a financial center, particularly an international one, also refers to a global city that provides a full spectrum of high-end services, as financial services cannot be independent on other specialized services. While a financial center can be seen as the pivot of financial network, a global city is the strategic control point in the organization of the world economy and in a multinational corporate network. It is hard to displace international financial services away from major international business and therefore difficult to separate an international financial center from a global strategic center. The terminologies of a financial center and global strategic center are inextricably related and inseparable. In a word, 
a strategic urban center or globalized city virtually performs high-end financial function. To be more explicit, one can argue that both financial centers and global cities are part of the global economy and share very similar locational requirements. Very often, comprehensive financial services are a leading industry and are a functional characteristic of a global city.

According to Sassen (1999 and 2001), global cities and global city-regions have emerged at a new scale in the dynamics of territorialization. Economic globalization and modern telecommunications are two factors contributing to the agglomeration of the new urban service economy that is based on cross-border networks as well as strategic locations with vast concentrations of competitive resources. To develop their global empire, MNCs tend to locate their headquarters in global cities where, under the global telecommunication network, their affiliates and subsidiaries around the world can be effectively controlled and coordinated. Specifically, MNCs seek competitive locations that are underpinned by many factors, including sufficient transportation and communication infrastructure; high quality of professional services such as legal, accounting, and financial services; rich social and cultural amenities; and good institutions rooted in the rule of law (Dicken, 1998). Therefore, MNC headquarters and high-end financial services are inextricably concentrated in the same key locations. This pattern of spatial co-location has contributed to the making of a global city or a global city-region (Scott, Angnew, Sojia, Storper, 2001).

One point to note from the identification of financial centers is that the regional headquarters of large non-financial corporations, especially those of MNCs, may provide indication about the importance of financial centers (Porteous, 1995, p.105; Dicken, 1998). This is because financial firms tend to be concentrated near the headquarters of their major clients, and equally, major clients may choose to remain or relocate as closer as possible to sources of funding and important financial services. It is common in the literature to use MNC headquarters concentration as an indication of a city's international business status. The presence of large companies in a city does affect the demand for the high level of financial 
services there. Usually, almost all MNCs with high rankings in influential business magazines are likely to set up regional headquarters in existing financial centers. It is obvious that financial sector agglomeration both reflects and reinforces real sector agglomeration (Porteous, 1999). On the one hand, firms tend to agglomerate to share with high-level producer services and to achieve the urbanization economies. Agglomeration makes firms economically viable. On the other hand, financial institutes tend to concentrate near the head offices of their major clients in order to serve them better. As Porteous (1995, p.92) discovered, through the case studies of Australia and Canada, there was a close correspondence between urban financial centers and cities which had a high proportion of large company head offices.

The existence of a financial center suggests that financial activities, like other businesses, tend to agglomerate spatially. Economic geography has long recognized that the location of economic activities in general and financial businesses in particular represents the outcome between centripetal and centrifugal forces (Krugman, 1991; Thrift, 1994; Martin, 1999; Porteous, 1999). The forces which cause spatial agglomeration of financial services are broadly similar to those in high-level services. To explain the formation and evolution of financial centers, scholars have pointed out some standard forces which cause spatial agglomeration of businesses in general and financial services in particular, such as a large pool of relevant skills, the availability of linked services like legal and accounting services, and localized spillovers of technology and information (Krugman, 1991). Also, financial services rely on information as an input and produce it as an output. Information is both the process and the product of financial services (Dicken, 1998, p.401). The ways in which information is generated and interpreted matter a great deal to the viability of financial institutions. In addition to these standard forces, there are also social and cultural as well as institutional determinants for financial agglomeration (Thrift, 1994; Porteous, 1995; 1999). Although there are decentralizing forces (such as innovations of telecommunication and 
information technology to reduce the friction of distance) at work in the financial sector, existing financial centers per se have clearly demonstrated that the forces of spatial agglomeration remain powerful.

If the financial sector has its high degree of spatial agglomeration, this agglomeration tends to be developed in a selected locality. One reason for that is path dependence, in which the initial conditions, to some extent, determine subsequent outcomes (Thrift, 1994). For example, the past successful track of financial firms in a particular locality might become a strong stimulation for new firms to aggregate there. However, the history of the process of development does not suffice, by itself, as a comprehensive explanation of the evolution of financial centers, because some researches have observed changes in the ordering of the financial center hierarchy nationally or regionally. The financial relationship between financial firms and other corporations cannot be standardized and hence require them to locate close to each other. Physical spatial distance may affect profitability especially when the service has high value-added content. The sunk cost of establishing an information-intensive relationship is high and the use of financial service is relatively infrequent. Based on location-specific pecuniary externalities in markets for skilled labor and the flow of specialized information, the increasing returns to location are likely to be strong for financial sector. For the existence of more fragmented information flows, it is necessary for the banking systems in developing countries to have special examination of the effects of distance on financial relationships (Porteous, 1995). The state and markets are balanced in terms of their respective sizes and financial resources. New market institutions play a dominant role in terms of the command of global finance. It is imperative to understand the urban infrastructure and development. Market is efficient when investments are properly priced in accordance with all the available information. It is impossible to systematically beat the market. Active investment must be justified by reference of benchmarks of performance, relative expertise and the availability of information (Clark, 1999). The rise and decline of 
financial centers over time suggest that the formation of financial centers cannot be understood merely with reference to historical trajectory.

Porteous (1995) proposes a theoretical framework to analyze why financial activities tend to agglomerate in one particular location rather than another. In his framework, Porteous has emphasized the key role of information flow, with regard to information accessibility and reliability, in influencing the location of financial activities. He has focused on the effect of two information concepts on financial center development: information hinterland and asymmetric information. The information hinterland of a center is defined as the region for which a particular core city, acting as the regional center, provides the best access point for the profitable exploitation of valuable information flows (Porteous, 1995). It can be measured by the patterns of information flow, although the measure is practically difficult due to data limitations. Within the information hinterland, valuable information flows first and with least cost. Information users closest to the heart of information hinterland are therefore able to act on earlier at lower costs than those far from the source of information. The value of information is also the function of social and economic characteristics of the hinterland center. As the potential opportunity and profitability of the financial sector depend much on the accessibility and reliability of information, the size and features of information hinterland is a key determinant appealing to financial firms. An important financial center tends to be developed in a politically and/or economically influential city with a strong information hinterland in terms of both information quantity and information quality.

The effect of asymmetric information would push financial firms closer to an information source in order to find and interpret non-standardized information from which to profit. There are many different cases of information asymmetry, depending on the types of information. In the reality of financial markets, there is a clear asymmetry of regulatory information in which administrative agents on one side of the market know something that participating agents on the other side do not. A financial firm, especially the foreign one, 
typically cannot know the local market regulations as accurately as the government. This is particularly relevant in the Chinese case as China has a very approval-intensive economy even after two decades of economic reforms. The Chinese government relies heavily on "rules", in the forms of laws, orders, regulations, and directives, to manage the economy. Besides the non-transparency problem, Chinese rules are normally expressed in generalities and cannot provide sufficient details to resolve practical matters. Implementation and enforcement of policy are, therefore, often subject to the interpretation and articulation of administrative authorities. Nonetheless, the authoritative interpretation and articulation usually come out in non-standardized and irregular formats and varies case by case. This means that formally published policy information cannot be interpreted correctly by information users, and that a wide range of non-standardized policy information becomes extremely crucial for doing businesses in China. However, non-standardized policy information cannot be effectively gathered without intensive social contacts to the information providers. The policy interpretation would not be favorable for a particular firm without frequent face-to-face negotiations to market regulators. Also, the quality and potential usefulness of non-standardized policy information may decay rapidly over the distance between information producers and information consumers. In some cases, the decay in such non-standardized information value over distance is very severe, the costs required to collect and verify the information of acceptable quality become very high, thereby making a remote party unprofitable. For the financial sector which business and level of profitability are highly sensitive to rapid dissemination of policy information, all these situations necessarily generate the importance of geographic proximity to the sources of non-standardized policy information in order to overcome the problem of asymmetric information. In China's case, major financial firms prefer locating their head-offices closest to the central government departments, the key generators of non-standardized policy information.

To summarize, the above review illustrates a number of general points with regard to 
the development of financial centers, some of which we will further investigate in the following sections. First, several quantifiable measures can be developed to identify financial centers when data availability allows. Second, financial activities and MNC regional headquarters may share similar locational characteristics and tend to locate nearby. Third, financial businesses need to collect, disseminate and interpret huge amount of information. High-level financial firms therefore seek to locate within the information hinterland of an international city, where information can be easily accessed and verified at lower costs. Fourth, in the prevalent presence of asymmetric information, geographic proximity between information generators and information users is paramount in reducing business costs and eventually determining the viability of financial firms even in the time when electronic communications are increasingly sophisticated and popular.

\section{Methodological Issues}

\section{$\underline{\text { Financial indicators }}$}

Some basic financial indicators as suggested by the literature, such as employment in the financial sector, the assets of financial institutions, bank cheque clearings, the value of turnover on the stock exchange, and the presence of foreign bank and financial institutions, can be used to understand the financial status of a city. We first present these indicators for major Chinese cities. It should be noted that, however, at the moment certain indicators are not very meaningful for Chinese cities because some financial services are not widely available. For example, the amount of bank cheque clearing is very small. At the personal level, the electronic payment system has not been widely used and the credit system is still immature.

To have a single figure to express a city's financial status and trace such status over time, the financial index (FINDEX) for Beijing and Shanghai is calculated. The FINDEX measures 
the significance of financial activities at the city level based on the factors pertinent to financial businesses. These factors include employment in the financial center, national bank loans, national bank deposit, total turnover value of stock exchanges, and the number of foreign banks and financial institutions. As these factors are essential for the assessment of the city's financial status, the importance of each factor is equally treated in the construction of the FINDEX. Each factor in a given city is first presented in terms of its share in the city's or in the nation's total. The share of each factor is then standardized to minimize the effects of differences in factor composition. The FINDEX is a sum of the standardized shared values for all factors. The greater FINDEX value indicates the higher financial status of the city.

\section{$\underline{\text { Surveys of MNC headquarters locations in China }}$}

To further understand the potential location of a national financial center in China, special attention is given to investigate the geographic concentration of MNC regional headquarters, as headquarters data may arguably provide a reasonable and convenient measure. It is widely observable that MNC regional headquarters and high-order financial activities are usually located side by side, and both utterly live on and are value-added on information. This observation, largely acknowledged in the extant literature on world cities, multinational corporations and geography of finance, has strongly suggested that the location choice of MNC regional headquarters shared similar requirements with that of high-order financial activities. For example, among other requirements, both are highly sensitive to information flows - information externality and asymmetry, and require ready access to high-value information. The easy accessibility and accurate interpretation of information, which are important to the agglomeration of financial activities, are also the key factors affecting the location of headquarters of MNCs. In this study, we use the presence of MNC headquarters as a powerful measurement and substitute for the information requirement for the development of high-end financial center and strategic global city, because in many cases the information effects, in terms of its externalities and asymmetry, are virtually 
non-quantifiable and immeasurable in reality.

While a sole reliance on headquarters location of MNCs to identify a financial center is by no means comprehensive, it is in fact, in our view, provides a useful proxy to discern the potential location status of financial activities, particularly in the Chinese context. It is worth noting that the Chinese financial market now has still been under tight controls, though the situation would change soon. Foreign financial institutions so far are prohibited from participating in a range of financial activities. Thus, application of many measures suggested by the literature based on an open market to examine the significance of past or current financial status of a particular city, such as the employment share of financial sector and the number of foreign banks, cannot well reflect the potential importance of a location as a prominent financial center in future. Given the common conception of co-location of high-order financial activities and MNC regional headquarters, therefore, empirical data on the location of MNC regional headquarters can arguably be a fair representation of the potential financial status of Chinese cities.

For the purpose of this study, it is necessary to distinguish the location choice of MNC regional headquarters (the location of strategic control) from that of MNC manufacturing bases (the location of FDI). Though both can be mobile in nature in the context of economic globalization, MNC regional headquarters and MNC manufacturing bases perform different roles which define different locational requirements. A regional headquarters coordinate and control the activities of the MNC's affiliates within a particular region, acting as an effective channel of transmitting instructions and information/interactions between the MNC's center and its affiliates (Dicken, 1998, p.209). It requires a strategic location on the international transport and communications network and with a strong pro-business environment in order to keep in just-in-time contact with other relevant parties which may be geographically dispersed. A manufacturing base, by contrast, is the location where the MNC can maximize its profits of product at given costs of productive factors (Dunning, 1998). 
There are numerous examples illustrating the point just highlighted: non-identical locations of MNC regional headquarters and its production base. That Boeing relocated its headquarters from its production base Seattle to a business strategic point Chicago in 2001 is one recent case to reflect different locational needs between a corporate headquarters and its manufacturing base. In China, despite Guangdong province was a major destination of the FDI during the 1990s (Table 1), it was not, at the same time, a concentrating location of MNC regional offices in the country. Beijing received the least FDI among three places surveyed, it however had the largest number of regional offices of foreign corporations.

Table 1 Realized Foreign Direct Investment in Beijing, Shanghai and Guangdong (in US\$ 100 million)

\begin{tabular}{|c|c|c|c|c|c|c|c|}
\hline Year & $\begin{array}{c}\text { National } \\
\text { total }\end{array}$ & \multicolumn{2}{|c|}{ Beijing } & \multicolumn{2}{c|}{ Shanghai } & \multicolumn{2}{c|}{ Guangdong } \\
\hline & Amount & Amount & $\begin{array}{c}\text { \% of } \\
\text { national } \\
\text { total }\end{array}$ & Amount & $\begin{array}{c}\text { \% of } \\
\text { national } \\
\text { total } \\
\text { national } \\
\text { total }\end{array}$ & Amount & \\
\hline 1995 & 378.0 & 27.3 & 7.2 & 32.4 & 8.6 & 121.0 & 32 \\
\hline 1996 & 418.7 & 15.5 & 3.7 & 39.4 & 9.4 & 117.5 & 28 \\
\hline 1997 & 523.8 & 20.6 & 3.9 & 36.3 & 6.9 & 150.9 & 28.8 \\
\hline 1998 & 452.8 & 21.6 & 4.8 & 36.0 & 7.9 & 120.1 & 26.5 \\
\hline 1999 & 452.8 & 19.7 & 5.0 & 28.3 & 7.1 & 116.5 & 29 \\
\hline 2000 & 407.1 & 16.8 & 4.1 & 31.6 & 7.8 & 112.8 & 28 \\
\hline
\end{tabular}

Sources: China Statistics Yearbook, various years; Guangdong Statistics Yearbook, various years; Beijing Statistics Yearbook, various years; Shanghai Statistics Yearbook, various years.

To learn the locational preference of MNC regional headquarters, a survey of headquarters of foreign-owned companies in four Chinese major cities (Beijing, Shanghai, Guangzhou, and Shenzhen) was conducted in summer 2000. These four cities are major financial centers in the Mainland China. The survey's samples are selected from the Directory of Standing Representative Organizations of Foreign and Territorial Companies in 
China (the 2000 edition), compiled and published by the Lotus Trade Center. For those four cities, 7 out of the total 18 industries listed in the Directory are selected as our sample base. These 7 industries are keys to the economy in general and are most relevant to financial center development in particular (for details on the 7 industries, see Table 2). Among about 6,000 foreign companies and offices (out of the total 9,946 in the Directory) in the 7 industries in four cities, about 1,000 firms commit in double counting because they have more than one subsidiaries. For any company that has more than one subsidiaries, only one of them - the headquarter is surveyed. So, our survey samples included 4793 foreign companies and offices. Among them, 2498 are regional headquarters in China (in charge of the whole China business), 2295 are China regional offices (in charge of China's local or regional business). This is a two-fold investigation: the first part is composed of a locational survey of foreign-owned headquarters; the second part is an investigation of the underlying locational factors.

Table 2 Industrial Category and Factors of the Survey

\begin{tabular}{ll}
\hline Industrial Category & Specification \\
\hline I & Advertising, news, gifts, consultancy, information and services \\
II & Finance, insurance, negotiable securities, law, bank \\
III & Machinery equipment, processing and manufacturing industry \\
IV & Post and telecommunications, computer, high technology, electronics \\
V & Commerce, trade, investment \\
VI & Transportation, freight forwarding, automobile, aviation and space flight, \\
& shipping and tourism \\
VII & Chamber of commerce, member organization, news organization \\
& \\
Factor Code & Factor Question \\
\hline A & Proximity to the central government departments \\
B & Government preferential business policies \\
C & Superior business environment and culture \\
D & Superior urban infrastructure and living environment \\
\hline
\end{tabular}


The survey was conducted by Lotus Trade Center with the help of some investment banks and financial institutions, including Morgan Stanley Dean Witter, and the Hong Kong General Chamber of Commerce. The Lotus Trade Center, based in Beijing, is an established publishing company for business information. It concentrates solely on collecting, processing and publishing of company and product information of foreign companies in China. The survey comprised of the in-depth interviews with selected senior officers, chief executive officer (CEOs) and the chief representatives of major banks and MNCs. The questions asked in the survey included general enterprise information, the existing and future office/premise locations in China and Hong Kong; locational preferences for branch/offices in China; and the reasons behind their location choices. The survey was mainly completed by phone and fax (one set of questions has been set for all interviewees), and was supplemented by some interviews conducted in person. Due to its affiliated relationship with the Ministry of Foreign Trade and Economic Relations, China’s central governing body in charge of foreign business, the Lotus Trade Center has the authority to collect data/information from every MNC in China. In other words, every MNC in China is obliged to provide its basic company data to the Center. Thus, the response rate of the survey is as high as $92 \%$.

The information about locations of foreign firms and offices is further supplemented by another survey from a global perspective - the survey of regional headquarter locations of Fortune 500 MNCs in mainland China and Hong Kong. Fortune Global 500 (2000) is an authorized listing of world's top MNCs ranked by revenue. The existing locations and locational propensity of regional headquarters or the first level subsidiaries of the world-largest MNCs provide an indicator of the overall attractiveness of the region for financial center development. This is a web-based survey. All of the information sources are explored from the Fortune websites as well as the corporation websites of the Fortune Global 500 corporations. The Internet sourcing is chosen because it provides accurate and up-to-date information about the locations of such corporations. Again, the web survey concentrates on the locations of the highest administrative unit of each surveyed corporation in the 4 largest 
Chinese financial centers.

The survey of locational factors involves interviewees from 2,498 foreign corporate headquarters in China. Again, the interviews were conducted by phone and fax, supplemented by some in-person-interviews, and the response rate was also as high as $90 \%$. Since the services and financial sectors in China are just in their 'infant' stage, we assume some factors affecting business locations, particularly non-economic ones such as expertise, professional how-how, labor forces, banking and financial operation system and infrastructure, to be equal among China’s major cities, such as Beijing, Shanghai, Guangzhou and Shenzhen. They are all situated in more or less at the same starting point in the development of financial and service sectors. Therefore, we focused on asking the chief/CEO why they had, or intended to, located their headquarters in their locating cities. Four locational factors were specifically selected. They are as follows: proximity to the central governmental units in China (Factor A); the government's preferential business policies that are designated to the region (Factor B); the superior business environment and culture (Factor C); and the superior urban infrastructure (Factor D) (see Table 2).

Two choices of factors, Factor A and Factor B, are critically designed and planned. Factor A is to testify the spatial effect of 'asymmetric information' generated from Beijing, the traditional and contemporary central governmental base in China, as well as the location of the highest administrative organs of state-owned enterprises. It is understandable that Beijing-based corporations can possess spatial advantage in the aspect of gaining better access to such 'regulatory information' that is substantially essential for doing business in China. Away from Beijing, access to such information becomes weaker, though there are still substantial government agents in the region possessing certain forms of administrative linkages to Beijing. In other words, it implies that Factor A is particularly designated to Beijing.

Factor B is specially designated to testify the spatial effect of the central government's 
special or preferential business policies that attract MNCs' headquarters to the region. It particularly refers to Shanghai, as the Pudong District in Shanghai has emphatically developed to be an economic center and a hub for other parts of the country, since Jiang Zemin, the party secretary of Shanghai municipality at that time, emphasized this development in 1988 (Zhao, 1994). Ten preferential business policies for the development of Pudong were issued when Pudong was declared as a special development area on 30 April 1990. ${ }^{1}$ In a few coastal open cities (namely, Special Economic Zones), including Guangzhou and Shenzhen, there are also preferential policies similar to those in Shanghai. Therefore, Factor $\mathrm{B}$ is particularly designated to investigate the locational impacts of the preferential policy on Shanghai, as well as the coastal opened cities of Guangzhou and Shenzhen. The other factors, Factor C and Factor D, are the two most essential components that are commonly requested to constitute a well-functioning financial center. This part of survey investigates which the factor is most important to determine headquarter locational preference in the respective city and industry.

\section{The Presence of MNC Regional Headquarters in China and Their Locational Factors}

Table 3 lists the actual number of MNC regional headquarters, broken down by cities.

The Table obviously depicts that MNC regional headquarters in the country is highly

concentrated in two cities, with Beijing and Shanghai having $88 \%$ of the all MNC regional

headquarters in mainland China. However, the Table recognizes the dominant position of

\footnotetext{
${ }^{1}$ The 10 preferential policies are related to the following: income tax of foreign investors; custom duties and tax for equipment, vehicles and building materials related to foreign investment; export-oriented foreign investments shall dominate the area; foreign investors are allowed to invest in infrastructure projects; foreign investors are allowed to operate tertiary industries; foreign banks are allowed to open foreign branches in Shanghai, including the Pudong New Area; a free trade zone will be established in the Pudong New Area; preferential treatment in terms of income tax reduction will be given to enterprises confirming with the industrial policies and beneficial to Pudong development; land leasing for 50-70 years will be used in Pudong. Foreign investors may contract large tracts of land for development; Pudong New Area can keep the revenue for further development. The policies were approved by the State Council on 30 April 1990. For details, see Pudong Development Office of Shanghai Municipality and People’s Construction Bank of China, Shanghai Branch , 1990; Shanghai Pudong New Area Administration , 1992; and Pudong Development Office of Shanghai Municipality, 1990.
} 
Beijing as a favorable location for MNC regional headquarters. Beijing looms over the others with 57\% of the total 2,498 MNC regional headquarters in China (excluding Hong Kong), nearly double the 773 headquarters in Shanghai, the second largest in the country, and Guangzhou-Shenzhen, plus all other places making-up only $12 \%$ of the total. The other places of the country make up only $7 \%$. This result is in contrast to common conception of national economic centers, in which Shanghai is usually referred to be the number one business center in China. In terms of regional headquarter offices of foreign multinationals and the regional headquarters of Pacific-Asian based companies, we see essentially the same picture. Beijing has $62 \%$ of the former and $50 \%$ of the latter; while Shanghai has $33 \%$ and $40 \%$, respectively (Table 3).

Table 3 Number (\%) of Foreign-owned Corporate Regional Headquarters, Regional Office and Pacific-Asia Headquarters in China (by mid-2000)

\begin{tabular}{|l|c|c|c|}
\hline & $\begin{array}{c}\text { China Regional } \\
\text { Headquarters Number } \\
(\%)\end{array}$ & $\begin{array}{c}\text { China Regional Office } \\
\text { Number (\%) }\end{array}$ & $\begin{array}{c}\text { Pacific-Asia Regional } \\
\text { Headquarters } \\
\text { Number (\%) }\end{array}$ \\
\hline Beijing & $1429(57)$ & $1419(62)$ & $10(50)$ \\
\hline Shanghai & $773(31)$ & $765(33)$ & $8(40)$ \\
\hline Guangzhou & $72(3)$ & $70(3)$ & $2(10)$ \\
\hline Shenzhen & $41(2)$ & $41(2)$ & $0(0)$ \\
\hline Other Chinese Regions & $183(7)$ & N/A & N/A \\
\hline Total & $2498(100)$ & $2295(100)$ & $20(100)$ \\
\hline
\end{tabular}

Note: Percentage figures in parentheses.

Source: The authors' survey.

Numerous business magazines feature annual ranking of the top corporations, from which the locations of MNC regional headquarters can be deduced. Utilizing the Fortune (2000) Global 500, we generate a comparison of top five Chinese cities, as measured by MNC regional headquarters and first-level subsidiaries (Table 4). As illustrated in the Table, Fortune's Global 500 data do not change the geographic pattern we found in our survey. Hong Kong, Beijing and Shanghai clearly dominate the list, forming a national triad. The geographic concentration of MNC regional headquarters in these 3 cities is evident and 
presents the status of these 3 cities in MNC networks. However, in terms of international influence, Fortune’s Global 500 relegates Beijing and Shanghai to a secondary rank behind Hong Kong. Nonetheless, Beijing is more influential than Hong Kong as a national center.

Table 4 Web Survey: Regional Headquarters and First-Level Subsidiaries Location of the Top MNCs in China

\begin{tabular}{|c|c|c|c|c|}
\hline City & $\begin{array}{c}\text { Regional/Local } \\
\text { Office }\end{array}$ & $\begin{array}{c}\text { China Regional } \\
\text { Headquarters }\end{array}$ & $\begin{array}{c}\text { Pacific-Asia Regional } \\
\text { Headquarters }\end{array}$ & Total \\
\hline Hong Kong & $\begin{array}{c}89 \\
(40)\end{array}$ & $\begin{array}{r}38 \\
(26)\end{array}$ & $\begin{array}{c}15 \\
(100)\end{array}$ & 142 \\
\hline Beijing & $\begin{array}{l}36 \\
(16)\end{array}$ & $\begin{array}{c}71 \\
(48)\end{array}$ & $\begin{array}{c}0 \\
(0)\end{array}$ & 107 \\
\hline Shanghai & $\begin{array}{l}35 \\
(16)\end{array}$ & $\begin{array}{r}29 \\
(19)\end{array}$ & $\begin{array}{c}0 \\
(0)\end{array}$ & 64 \\
\hline Guangzhou & $\begin{array}{l}15 \\
(7)\end{array}$ & $\begin{array}{c}5 \\
(3)\end{array}$ & $\begin{array}{c}0 \\
(0)\end{array}$ & 20 \\
\hline Shenzhen & $\begin{array}{c}4 \\
(2)\end{array}$ & $\begin{array}{c}0 \\
(0)\end{array}$ & $\begin{array}{c}0 \\
(0)\end{array}$ & 4 \\
\hline Others & $\begin{array}{r}46 \\
(20)\end{array}$ & $\begin{array}{c}6 \\
(4)\end{array}$ & $\begin{array}{c}0 \\
(0)\end{array}$ & 52 \\
\hline Total & $\begin{array}{l}225 \\
(100)\end{array}$ & $\begin{array}{c}149 \\
(100)\end{array}$ & $\begin{array}{c}15 \\
(100)\end{array}$ & 389 \\
\hline
\end{tabular}

Notes: Percentage figures in parentheses. For a single company, more than one office may be counted among the selected cities. Also, when the headquarters and the first-level subsidiary of the same MNC locate in the same city, only one is counted. When the multiple first-level subsidiaries locate in the same city, also only one is counted.

Source: Fortune (2000) Global 500 (www.fortune.com/fortune/global500)

Table 5 shows the relative importance of 4 factors affecting the location choice of MNC regional headquarters in China. In general, factors such as "proximity to central policy-making departments” (factor A), “business environment” (factor C) and “infrastructure” (factor D) are important in all industries surveyed, together accounting for 
83\% of the total. But the factor of "preferential policies" (factor B) ranks the lowest, indicating that the favorable policy is not necessarily a primary concern of MNCs for locating their regional headquarters.

Table 5 Importance of Locational Factors Attracting MNC Regional Headquarters in China, by Industry

\begin{tabular}{|c|c|c|c|c|c|}
\hline \multirow{2}{*}{$\begin{array}{l}\text { Industrial } \\
\text { Category }\end{array}$} & \multicolumn{4}{|c|}{ Factor } & \multirow[t]{2}{*}{ Total } \\
\hline & $A$ & B & $C$ & D & \\
\hline \multirow[t]{2}{*}{ I } & 156 & 95 & 204 & 189 & 644 \\
\hline & (24) & (15) & (32) & (21) & (100) \\
\hline \multirow[t]{2}{*}{ II } & 45 & 23 & 36 & 27 & 131 \\
\hline & (34) & (18) & (27) & (21) & (100) \\
\hline \multirow[t]{2}{*}{ III } & 78 & 49 & 79 & 86 & 292 \\
\hline & (27) & (17) & (27) & (29) & (100) \\
\hline \multirow[t]{2}{*}{ IV } & 89 & 50 & 82 & 75 & 296 \\
\hline & (30) & (17) & (28) & (25) & (100) \\
\hline \multirow[t]{2}{*}{$\mathrm{V}$} & 81 & 44 & 60 & 57 & 242 \\
\hline & (33) & (18) & (25) & (24) & (100) \\
\hline \multirow[t]{2}{*}{ VI } & 61 & 33 & 35 & 34 & 163 \\
\hline & (37) & (20) & (21) & (21) & (100) \\
\hline \multirow[t]{2}{*}{ VII } & 1 & 1 & 11 & 4 & 17 \\
\hline & (6) & (6) & (65) & (24) & (100) \\
\hline \multirow[t]{2}{*}{7 Industries } & 511 & 295 & 507 & 472 & 1785 \\
\hline & (29) & (17) & (28) & (26) & (100) \\
\hline
\end{tabular}

Notes: Percentage figures in parentheses. Explanations of industrial categories and factors refer to Table 2. Source: The authors' survey.

From a glance at the figures, it emerges clearly that "proximity to central policy-making departments” (factor A) is at the top of the importance hierarchy in several industries. In financial and commercial sectors (categories II and V), information and hi-tech industries (category IV), and transportation-related industries (category VI), factor A holds a leading position and constitutes over $30 \%$ of the entire consideration. In service and manufacturing industries (categories I and III), although factor A is not at the first rank, it still 
has considerable shares, $24 \%$ and $27 \%$, respectively. The significance of factor A demonstrates that, for most types of industry, MNC regional headquarters prefer to the location where there are many functional departments of the central government.

Among the seven industries surveyed, business organizations (category VII) give a heavy weight on business environment (factor C). It is understandable that a good business environment fosters and sustains healthy business. In this industry, infrastructure (factor D) is also relatively significant, with $24 \%$ of the total. These two factors are actually crucial for other industries too. By contrast, the impact of preferential policies (factor B) on the location choice of MNC regional headquarters seems not as important as commonly perceived.

Table 6 presents the survey result of locational factor importance in four Chinese key cities. As shown in the Table, MNCs locate their regional headquarters in different cities for different concerns. Beijing was chosen primarily because of its proximity to departments of the central government, thought its business environment and infrastructure are also important. In the other three cities, most of the attraction of MNC regional headquarters to these localities seems to lie in their intention to take advantage of good business environment and infrastructure there. Most surveyed companies ranked "business environment” (factors C) and "infrastructure" (factor D) as the first two choices. Overall, the results reflect that different cities have different locational advantages in affecting MNC's choice of regional headquarters in China.

Table 6 Importance of Locational Factors Attracting MNC Regional Headquarters in China, by City

\begin{tabular}{|c|c|c|c|c|c|}
\hline \multirow{2}{*}{ City } & \multicolumn{4}{|c|}{ Factor } & \multirow{2}{*}{ Total } \\
\cline { 2 - 5 } & $\boldsymbol{A}$ & $\boldsymbol{B}$ & $\boldsymbol{C}$ & $\boldsymbol{D}$ & \\
\hline Beijing & 436 & 202 & 285 & 256 & 1179 \\
\hline
\end{tabular}




\begin{tabular}{|c|c|c|c|c|c|}
\hline & $(37)$ & $(17)$ & $(24)$ & $(22)$ & $(100)$ \\
\hline Shanghai & 52 & 77 & 173 & 177 & 479 \\
& $(11)$ & $(16)$ & $(36)$ & $(37)$ & $(100)$ \\
\hline \multirow{2}{*}{ Guangzhou } & 12 & 7 & 35 & 27 & 81 \\
& $(15)$ & $(9)$ & $(43)$ & $(33)$ & $(100)$ \\
\hline \multirow{2}{*}{ Shenzhen } & 11 & 9 & 14 & 12 & 46 \\
& $(24)$ & $(20)$ & $(30)$ & $(26)$ & $(100)$ \\
\hline
\end{tabular}

Notes: Percentage figures in parentheses. Explanation of factors refers to Table 2.

Source: Same as Table 5.

Investigation of Hong Kong's case provided additional empirical support to the importance of information accessibility to the location selection of foreign corporation headquarters (Table 7). Table 7 tabulates the ranking of various factors attracting to set up a regional head-office in Hong Kong. According to a survey done in 2001,among 3,001 Hong Kong-based multinational companies (many of them are financial institutions), more than $82 \%$ of them believed that their first consideration in locating their regional headquarters or regional offices in Hong Kong was because of its good accessibility of information. In fact, as an emerging world city, Hong Kong has a more pronounced advantage in information flows and asymmetric information (such as financial regulations and 'political' information related to financial sector) comparing with most of the other international cities in East Asia.

Table 7 Importance of Factors Affecting Hong Kong as a Location for a Regional Headquarters of Multinational Corporations

\begin{tabular}{|l|c|c|c|c|}
\hline \multirow{2}{*}{ Factor } & \multirow{2}{*}{$\begin{array}{c}\text { Ranking of } \\
\text { importance* }\end{array}$} & \multicolumn{3}{|c|}{ Number of company } \\
& & In parentheses the percentage)
\end{tabular}




\begin{tabular}{|c|c|c|c|c|}
\hline & & (83.5) & $(1.2)$ & $(15.4)$ \\
\hline Rule of law & 5 & $\begin{array}{l}2127 \\
(70.9)\end{array}$ & $\begin{array}{c}154 \\
(5.1)\end{array}$ & $\begin{array}{c}720 \\
(24.0)\end{array}$ \\
\hline English communication skill & 6 & $\begin{array}{c}2146 \\
(71.5)\end{array}$ & $\begin{array}{c}242 \\
(8.1)\end{array}$ & $\begin{array}{c}613 \\
(20.4)\end{array}$ \\
\hline Geographical location & 7 & $\begin{array}{l}2449 \\
(81.6)\end{array}$ & $\begin{array}{c}30 \\
(1.0)\end{array}$ & $\begin{array}{c}522 \\
(17.4)\end{array}$ \\
\hline Government economic policy & 8 & $\begin{array}{c}1920 \\
(64.0)\end{array}$ & $\begin{array}{c}166 \\
(5.5)\end{array}$ & $\begin{array}{c}915 \\
(30.5)\end{array}$ \\
\hline Staff cost & 9 & $\begin{array}{c}1666 \\
(55.5)\end{array}$ & $\begin{array}{c}592 \\
(19.7)\end{array}$ & $\begin{array}{c}743 \\
(24.8)\end{array}$ \\
\hline Cost of office space & 10 & $\begin{array}{c}1495 \\
(49.8)\end{array}$ & $\begin{array}{c}858 \\
(28.6)\end{array}$ & $\begin{array}{c}648 \\
(21.6)\end{array}$ \\
\hline Availability of professional/skills & 11 & $\begin{array}{c}2239 \\
(74.6)\end{array}$ & $\begin{array}{c}114 \\
(3.8)\end{array}$ & $\begin{array}{c}648 \\
(21.6)\end{array}$ \\
\hline Adequacy of supporting services & 12 & $\begin{array}{l}2232 \\
(74.4)\end{array}$ & $\begin{array}{c}70 \\
(2.3)\end{array}$ & $\begin{array}{c}655 \\
(21.8)\end{array}$ \\
\hline Availability of managerial skill & 13 & $\begin{array}{c}2251 \\
(75.0)\end{array}$ & $\begin{array}{c}85 \\
(2.8) \\
\end{array}$ & $\begin{array}{c}665 \\
(22.2) \\
\end{array}$ \\
\hline Infrastructure & 14 & $\begin{array}{c}2391 \\
(79.7)\end{array}$ & $\begin{array}{c}60 \\
(2.0)\end{array}$ & $\begin{array}{c}550 \\
(18.3)\end{array}$ \\
\hline Political climate & 15 & $\begin{array}{r}1726 \\
(57.5)\end{array}$ & $\begin{array}{r}266 \\
(8.9) \\
\end{array}$ & $\begin{array}{r}1009 \\
(33.6) \\
\end{array}$ \\
\hline Intellectual property protection & 16 & $\begin{array}{c}1767 \\
(58.9)\end{array}$ & $\begin{array}{l}273 \\
(9.1)\end{array}$ & $\begin{array}{c}961 \\
(32.0)\end{array}$ \\
\hline Linked exchange rate system & 17 & $\begin{array}{c}1904 \\
(63.4)\end{array}$ & $\begin{array}{c}147 \\
(4.9)\end{array}$ & $\begin{array}{c}950 \\
(31.7)\end{array}$ \\
\hline Availability of suitable office & 18 & $\begin{array}{c}2017 \\
(67.2) \\
\end{array}$ & $\begin{array}{r}245 \\
(8.2) \\
\end{array}$ & $\begin{array}{c}739 \\
(24.6) \\
\end{array}$ \\
\hline Local market potential & 19 & $\begin{array}{r}1721 \\
(57.3) \\
\end{array}$ & $\begin{array}{l}297 \\
(9.9) \\
\end{array}$ & $\begin{array}{c}983 \\
(32.8) \\
\end{array}$ \\
\hline Labor productivity & 20 & $\begin{array}{c}1877 \\
(62.6)\end{array}$ & $\begin{array}{l}203 \\
(6.8)\end{array}$ & $\begin{array}{c}921 \\
(30.7)\end{array}$ \\
\hline
\end{tabular}

* This is Hong Kong Government's Survey. In this survey, the total number of companies investigated is 3001. Each respondent was asked to rate the importance of the 20 factors. Ratings provided by individual companies were used to produce an overall ranking.

Source: Census and Statistics Department, Hong Kong Special Administrative Region, 2000 survey of regional offices representing overseas companies in Hong Kong

It is very interesting to see, from Table 7, that 'Accessibility of information', 'Cleanliness of government', and 'Tax regime' are the top three priorities, followed by 
'Bank\& financial facilities', 'Rule of law', and 'English skill' criteria. While the factors of costs (staff and space), skills (professional and managerial) and infrastructure (physical and supporting) are prioritized relatively less important (below top 8), the rest, including political climate, property right, labor productivity, are prioritized least. This is in much contrary to the conventional theory of firm's location, in which cost, skill, infrastructure, and productivity are overwhelmingly prioritized. This spells out the significant difference of locational choices between headquarter offices and their operational units, such firms and manufacturing factories. Above all, this highlights the importance of information flow and asymmetric information in headquarters location in general and financial/service centers' development in particular, as, in spatial terms, agglomeration of headquarters, particular financial ones, will lead to the emergence or growth of a financial/service center. The finding from the investigation in Hong Kong is consistent with the overall findings of this paper.

\section{Analysis of Financial Status of Beijing and Shanghai}

From our headquarters survey, both Beijing and Shanghai are identified as the most prominent national high-end financial and service centers in China. The potential of other cities, such as Guangzhou's and Shenzhen's one, is relatively minor. So, in the following comparative analysis of financial status, we will focus primarily on Beijing and Shanghai. Table 8 documents the trend of the employment in Finance, Insurance and Real Estate (FIRE) activities as percentage of total metropolitan labor force. In general, the share of people working in the FIRE sector is quite low in both cities. This indicates that, compared to other major financial cities in the world, both cities have not gained an important position in the global financial market. However, the employment share in the FIRE sector has notably risen in the 1990s. From the figure, we can see that Beijing has a higher share of labor employed in the FIRE sector than Shanghai. 
Table 8 Employment in FIRE sector as \% of total city's labor force

\begin{tabular}{ccc}
\hline Year & Beijing & Shanghai \\
\hline $\mathbf{1 9 8 1}$ & 0.36 & 0.28 \\
$\mathbf{1 9 8 5}$ & 0.49 & 0.32 \\
$\mathbf{1 9 9 0}$ & 0.66 & 0.46 \\
$\mathbf{1 9 9 5}$ & 1.90 & 1.50 \\
$\mathbf{2 0 0 0}$ & 3.17 & 2.25 \\
\hline
\end{tabular}

Source: Calculated from China Statistic Yearbook 1981-2001

Table 9 lists the loans granted by financial institutions in Beijing and Shanghai. From it, we can see that financial institutions of Shanghai issued more loans than that of Beijing. It is also worth noting that in the late 1970s, loans granted in Shanghai tripled that in Beijing. But in recent years, the difference had been narrowed down. By the end of 2000, Beijing even overtook Shanghai for the first time.

Table 9 Loans of financial institutions in Beijing and Shanghai (100 million RMB)

\begin{tabular}{ccc}
\hline Year & Beijing & Shanghai \\
\hline $\mathbf{1 9 7 8}$ & 53.9 & 153.4 \\
$\mathbf{1 9 8 3}$ & 149.5 & 239.5 \\
$\mathbf{1 9 8 8}$ & 415.7 & 576.1 \\
$\mathbf{1 9 9 3}$ & 971.5 & 1605.6 \\
$\mathbf{1 9 9 5}$ & 1560.6 & 2387.3 \\
$\mathbf{1 9 9 8}$ & 3126.2 & 4259.7 \\
$\mathbf{1 9 9 9}$ & 3761.3 & 4862 \\
$\mathbf{2 0 0 0}$ & 5666.8 & 5415.7 \\
\hline
\end{tabular}

Sources: Comprehensive statistical data and materials on 50 years of new China / compiled by Department of Comprehensive Statistics of National Bureau of Statistics, Beijing, China

However, from the total amount of deposits of financial institutions in Beijing and Shanghai, we can see a different picture (Table 10). Beijing always has a bigger amount of deposits than Shanghai. In China, as the deposit amount is the main body of financial liabilities residing in the cities, it also can be seen as an indicator to show funding supplies of 
each city.

Table 10 Deposits of financial institutions in Beijing and Shanghai (100 million RMB)

\begin{tabular}{ccc}
\hline Year & Beijing & Shanghai \\
\hline 1978 & 115 & 243 \\
1983 & 321 & 191 \\
1988 & 610 & 420 \\
1993 & 1649 & 1495 \\
1995 & 3054 & 3057 \\
1998 & 6369 & 5595 \\
1999 & 7907 & 6271 \\
2000 & 9261 & 6926 \\
\hline
\end{tabular}

Sources: Comprehensive statistical data and materials on 50 years of new China / compiled by Department of Comprehensive Statistics of National Bureau of Statistics, Beijing China

Table 11 shows the distribution of the turnover of securities transaction in Beijing and Shanghai. For Shenzhen Stock Exchange (SZSE), the distributed data are available for recent three years. For Shanghai Stock Exchange (SSE), because they decentralize their transactions to regional trading centers around the country, trading volumes within each trading center have been deemed as the distributed data of SSE. Therefore, the total transaction volume in both Beijing and Shanghai consists of two parts (one from SSE, the other from SZSE). Their sum-up is the ultimate turnover. In that, Shanghai’s market proportion has a notable advantage, overwhelming Beijing over twice. The finding shows that Shanghai is already in a leading position in terms of the transaction volume of stock and securities in China.

Table 11 Turnover of Stock and Securities Transaction in Beijing and Shanghai (100 million yuan)

\begin{tabular}{ccccccc}
\hline & \multicolumn{2}{c}{ Beijing } & \multicolumn{3}{c}{ Shanghai } \\
& SSE & SZSE & Total & SSE & SZSE & Total \\
\hline $\mathbf{1 9 9 9}$ & NA & 2249.9 & NA & NA & 3677.5 & NA \\
$\mathbf{2 0 0 0}$ & 9812.7 & 4078.4 & $\mathbf{1 3 8 9 1 . 1}$ & 26114.6 & 7924.2 & $\mathbf{3 4 0 3 8 . 8}$ \\
$\mathbf{2 0 0 1}$ & 10318.5 & 1875.5 & $\mathbf{1 2 1 9 4}$ & 23366.4 & 3460.5 & $\mathbf{2 6 8 2 6 . 9}$ \\
\hline
\end{tabular}


Sources: Shenzhen Stock Exchange Fact Book 1999, 2000, 2001

Shanghai Stock Exchange Yearbook 1999, 2000, 2001

Note: SSE refers to Shanghai Stock Exchange; SZSE refers to Shenzhen Stock Exchange

Table 12 shows the geographic distribution of foreign bank branches and representative offices in China in the late 1990s. In terms of bank branches, Shanghai has $30 \%$ of the national total, ranking number one. Shenzhen has 15\%, Beijing $11 \%$ and Guangzhou 10\%, ranking second, third and fourth, respectively. This finding shows that Shanghai is the largest financial retailing outlet in China.

Table 12 Distribution of Bank Branches ${ }^{1}$ and Representative Offices $^{2}$ of Foreign Institutions in China (1998)

Foreign-owned Bank Branch

(\%)

\begin{tabular}{ccc} 
& $\mathbf{( \% )}$ & $\mathbf{( \% )}$ \\
\hline Beijing & $16(11)$ & $122(44)$ \\
Shanghai & $45(30)$ & $68(25)$ \\
Guangzhou & $15(10)$ & $23(8)$ \\
Shenzhen & $23(15)$ & $10(4)$ \\
Other Chinese Regions & $53(35)$ & $54(19)$ \\
Total & $152(100)$ & $277(100)$
\end{tabular}

Source: Association of China's Finance and Banking (1999), Almanac of China's Finance and Banking, Beijing China, pp. 550-551.

${ }^{1}$ Solely foreign-owned

${ }^{2}$ Solely foreign-owned or foreign-China joint venture

However, in terms of the representative offices of foreign financial institution, which perform the administrative function, Beijing had the largest share (44\%), while Shanghai 
accounted for only 25\%. The shares of Guangzhou, Shenzhen and the rest of China altogether were only $31 \%$. This finding shows that Beijing is already in a leading position in terms of agglomerating the administrative offices of foreign financial institutions in China. From the historical data, we can see that in the past Beijing had always a larger number of foreign banks representative offices than Shanghai (Table 13).

Table 13 Number of Foreign Bank Representative Offices in Beijing and Shanghai

\begin{tabular}{ccc}
\hline & Beijing & Shanghai \\
\hline 1985 & 90 & 21 \\
1988 & 106 & 34 \\
1991 & 120 & 32 \\
$\mathbf{1 9 9 4}$ & 193 & 98 \\
$\mathbf{1 9 9 7}$ & 219 & 165 \\
$\mathbf{2 0 0 0}$ & 111 & 57 \\
\hline
\end{tabular}

Source: Almanac of China's Finance and Banking, Beijing China, various years

We have so far examined several indicators by which we may understand the importance of a financial sector in a given city. From the data shown, the relative strength or weakness of a particular city as a financial center can be assessed. However, no single indicator can tell the full story. For example, Beijing is more attractive, relative to Shanghai, as a head office location of large Chinese banks, although it has a smaller number of foreign banks. In terms of stock exchange volume, Shanghai is in a dominant position. To present an overall picture of the financial status for a particular city by a single measure and to make more precise comparison between Beijing and Shanghai, we therefore construct the FINDEX for these two cities. Taking into account the data availability, we use the following five variables.

1. Employment in the financial sector;

2. Bank loans; 


\section{Bank deposits;}

4. Turnover value of the stock exchange;

5. Number of foreign banks and financial institutions.

As it is hard to argue which variable is more important than the others in assessing a city's financial status, each variable is given an equal weight and its percentage as the city's or the national total is calculated. The FINDEX is a sum of the standardized percentage values for all five variables. The maximum value of the FINDEX, in our case, is 500 if all financial activities measured by these 5 variables took place just in one city.

Figure 1 FINDEX for Beijing and Shanghai, 1990-2000

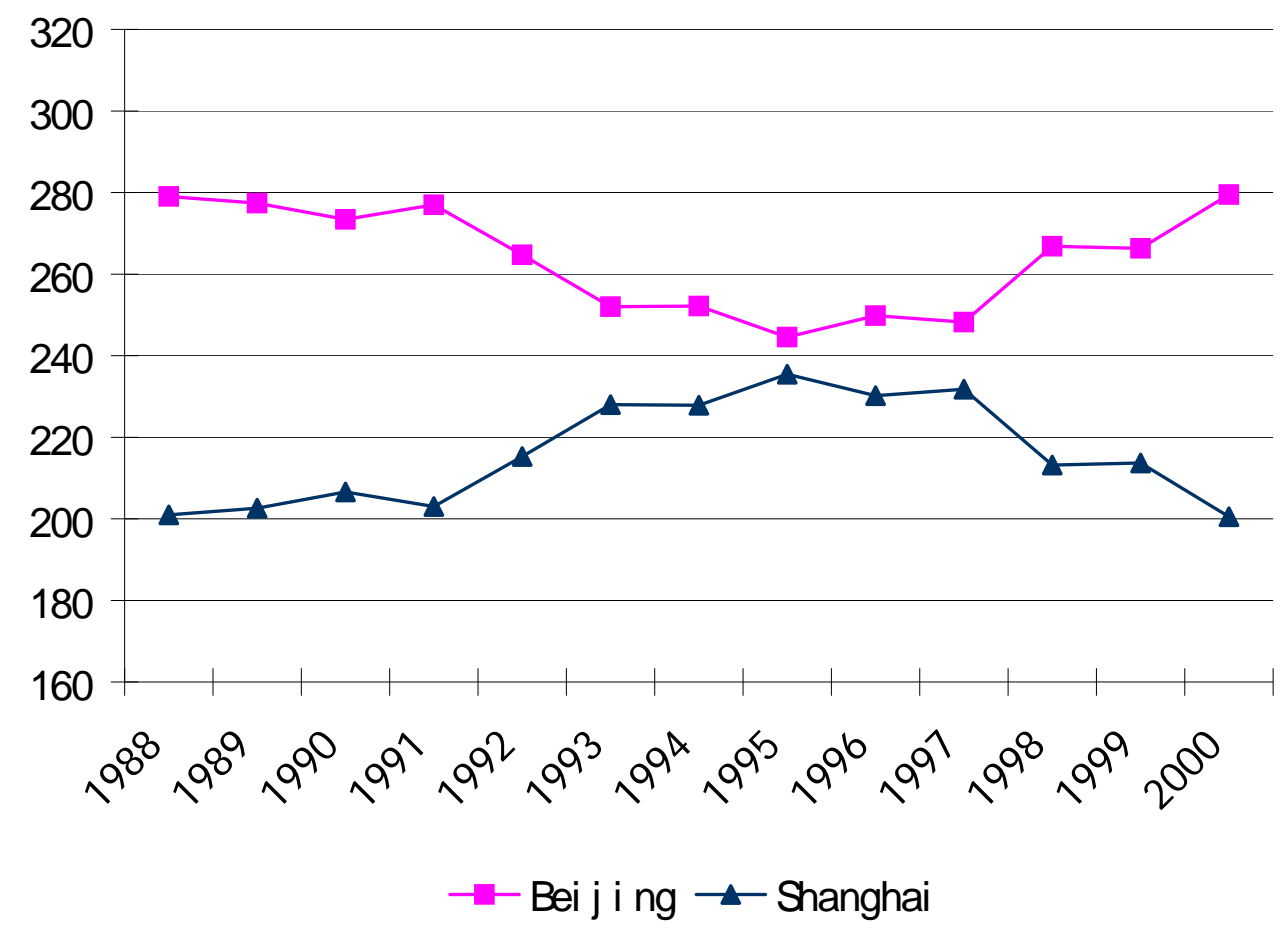

Source:

Figure 1 shows the changes in the FINDEX value for Beijing and Shanghai in the 1990s. Before 1991, the FINDEX value of Beijing was much higher than that of Shanghai, indicating a much higher financial status of Beijing. After 1991, the FINDEX value of Shanghai was 
rising and Beijing's one was declining. Shanghai was catching up fast. In 1995, two cities were highly similar in their FINDEX values. After 1998, one can observe the opposite trend. The FINDEX value of Beijing was rising and the FINDEX value of Shanghai was precipitously falling, once again enlarging the FINDEX gap between two cities. As of 2000, the FINDEX value for Beijing was 280, whereas only 200 for Shanghai. The comparison of the FINDEX values for two cities indicates, whatever the common perception about Shanghai's financial status, that Beijing continues its leading position as a national largest financial center, even though the central government has made great effort in the past few years to promote Shanghai to be China’s number one financial center.

Our FINDEX results seem consistent with other research findings. An influential study of the urban competitive ranking reported that among Chinese cities Shanghai ranked the top in terms of overall competitiveness, followed by Beijing, Shenzhen and Guangzhou (http://finance.sina.com.cn, 18 October 2001). However, Beijing ranked the number one in financial competitiveness. Financial competitiveness in the study refers to the ability and potential to develop the capital market and financial industries. As the study pointed out, Beijing as the national capital possesses many advantages for internationalization and infrastructure development. In China, Beijing's overall economic power is next only to Shanghai. Beijing is also the country's largest science and technology hub with more 70 universities and 400 research institutes. Since the top universities and research institutes are most located in Beijing, the city has developed very strong IT industries. Moreover, Beijing as the national political center is the major source of political and economic information. It is in Beijing that the central government and all ministries exert their management power. The designation of the 2008 Olympics Games to Beijing has further given the city more opportunities for development of finance-related industries. The study concluded that all these advantages made Beijing extremely attractive to MNC headquarters and international financial institutions. 


\section{Information Requirements and the Formation of A Financial Center}

As reviewed in the second section, there are many factors determining the formation of a financial center in certain localities and the location of choice of MNC regional headquarters. As we discussed earlier, the results of MNC headquarters survey indicated that regional headquarters of MNCs in Beijing was outnumbered those in Shanghai (section 4). An examination of some basic financial indicators showed that Beijing and Shanghai had different advantages in different financial respects (section 5). An analysis of the FINDEX also revealed that Beijing had a higher value, standing above Shanghai in the overall financial status (section 5). To someone such findings on Shanghai are disquieting are demanding more interpretation.

For the differences between Beijing and Shanghai in the attractiveness of foreign headquarters and the development of financial market, a critical determining factor, among others, which should be singled out, is the information requirement: information externalities and asymmetry. Apart from various pulling factors already highlighted in location theories such as agglomeration economies, information externalities and asymmetry, which seem less attended in classic economic geography, have played a decisive role in the spatial concentration of MNC regional headquarters and the formation of a national financial center in Beijing.

From our perspective, an information externalities and asymmetry between market regulators and market participants provides a rationale for MNC regional headquarters in general and financial activities in particular agglomerating in the source of regulation information. The asymmetry of information exists between market regulators and market participants when market regulations are subject to various interpretations. In contemporary China, the state still controls more than $50 \%$ of the national economy even after two decades of decentralization reforms. Industries, especially those strategic ones, are essentially ministry-led in administration and operation. Business and financial markets are highly regulated by various functional departments of the central government. This can be exemplified by the "risk of politics" and the "risk of polity". The "risk of politics" refers to frequent changes in regulatory policies over time, which means that the policy focus, as implemented in practice, would be inconsistent from one time to another. The "risk of polity" 
refers to that government control organs is frequently shifting from one government department to another from time to time over a particular sector, which would introduce a redistribution of vested interests among particularistic departments and would often create opposing forces. Regulations for the financial services of foreign firms, for example, are formulated by many government departments like the Ministry of Foreign Trade, the Office of Foreign Affairs, and the Office of Foreign Investments, each of them administering one or more aspects of foreign financial services. Implementation of the regulations is subject to the interpretations articulated by the departments in charge. Because of the "risk of politics" and the "risk of polity", it can be expected that, very often, the interpretations from different departments are completely different or even contradictory each other. The process to pursue a specific financial policy is largely determined by the cross-ministerial struggle. This can create a destructive effect on business and financial markets in an unpredictable and instant manner, usually signaled by a turbulent change of the stock price of listing companies.

There are many examples showing that policy information is plagued by extreme asymmetries in China. One is about the cable-TV operations. In late November 2000, the People's Daily, traditionally an official source of information in China, announced that foreign investors would be allowed to engage in the "value-added telecommunications services” through cable-TV. Two days after the announcement, an official from the State Administration of Radio, Film and Television wrote to the newspaper China Securities, denying the announcement from the People's Daily. He emphasized that foreign investment on cable-TV in China was still prohibited. These contrasting interpretations concerning cable-TV operations made the stock price of CITIC Pacific, one of the biggest investors in China cable-TV networks, suddenly fall $8.2 \%$ in one day in its Hong Kong listings (South China Morning Post, 30 November 2000). A fund manager described the situation meaningfully in simple words. "Yesterday, one government official said one version, then today someone else came out with another version. No one knows which one is true" (South 
China Morning Post, 30 November 2000).

The above case simply illustrates that the relationship between market regulators and market participants is especially subject to problems of asymmetric information. Market regulators typically have more knowledge of market regulations than do market participants. In order to reduce the risk of informational asymmetry, market participants must find ways to know policy details and to verify policy interpretations as soon as possible, and, finally, to anticipate trade-offs of potential decisions. One effective way to do so is to keep close face-to-face contacts with relevant government authorities, the source of policy information. Obviously, the friction of distance necessarily limits the frequency of contact by making it costly in terms of time and travel expenditure. This is why MNC regional headquarters and financial firms tend to highly agglomerate in Beijing, the center of economic control and the "heartland" of policy information. In fact, one hardly finds the same scale of agglomeration of MNC regional headquarters elsewhere in the country.

The major consequence from the intervention is that the asymmetric information underlies China's financial markets. Lenders offering credit to borrowers face uncertainty about their creditworthiness to the extent that they cannot observe some of the borrowers' characteristics and actions. These informational asymmetries cause adverse selection and moral hazard problems and may invalidate standard competitive market result. In China, the situation is extremely severe. As markets expand, China requires intermediaries to bring buyers and sellers together and solve the problem of asymmetric information that bedevils financial markets. When specialized intermediaries do their job well, they reduce adverse selection problems between savers and entrepreneurs by transmitting accurate information about investment opportunities. This transmission, however, requires overcoming the moral hazard that arises from the intermediaries and their clients: when intermediaries play a substantial role, they acquire important information about the participants in financial markets. Typically, such intermediaries will have more information about their clients than 
intermediaries, without access to such privileged information, offer their clients service of lower value. As a result, clients may not easily change networks or contacts and the intermediary should fail to provide optimal services. Because the client's intermediary will undoubtedly be cognizant of this, he can easily take advantage of his client. At present, in China, as intermediaries often possess privileged information by virtue of links to government officials, the moral hazard problems come to forth. This problem is amplified because personalized networks of power brokers within the party bureaucracy are the main source of an intermediary's credibility, making the quality of the information proffered difficult to be evaluated publicly. In a sense, China's financial intermediaries can be deemed as in effect private brokers of public information. Secrecy or ambiguity in the rules is essential to their deal-making role. So far, as that power and politics, rather than rules, control the information needed to price financial capital, the problem of asymmetric information is serious.

Given an assumption that MNC regional headquarters and financial firms need to proximate to the center of policy information in order to reduce informational asymmetry, Beijing's potential strength as a financial center rests on its national significance of administration and regulations. Beijing plays an irreplaceable role in implementing the country's financial policies and in the decision-making and adjustment of the macro-economic policies. In fact, Beijing has already hosted many domestic and joint-ventured financial institutions, including China Securities Regulatory Commission, China Insurances Regulatory Commission, all China’s major banks, China International Trust and Investment Corporation, China International Capital Corporation, and Everbright Securities. This status will accelerate Beijing's pace toward becoming an international financial metropolis. This is not to say that other cities, such as Shanghai, are not important in the Chinese financial markets. Nor is it to be little Shanghai's international significance. Shanghai may have a prominent role in developing various kinds of financial services. But its strength as the national number one financial center may not be as strong as Beijing, simply 
because of the effect of asymmetric information. Nonetheless, we are not to say that other factors do not play a role in the formation of a financial center. Rather, we argue that the effect of asymmetric information can be very crucial in certain cases, particularly in the Chinese case where the economy is strongly state-regulated.

\section{Concluding Remarks}

This paper explores, theoretically and empirically, one of the important issues of the geography of finance: the location of high-level financial services. Specifically, we try to explain why foreign financial services are spatially concentrated on a particular city to form a national financial center in China. Assuming that the location of MNC regional headquarters can serve as a reasonable proxy to the location status of financial activities, our approach to explore the formation of a financial center is to investigate the effect of asymmetric information on the spatial agglomeration of MNC regional headquarters. We view that the effect of asymmetric information, to a great extent, can be decisive for the geographic concentration of economic activities in general and financial services in particular. Based on the survey of the actual location of MNC regional headquarters and reasons of the headquarters agglomeration, as well as an analysis of some financial indicators, we anticipate that Beijing, as the prime source of policy information, is more advantageous than other Chinese cities to be the national number one financial center when the Chinese financial markets become more open to foreign firms in the near future.

This study, which represents a somewhat different way of thinking about the development of financial centers, challenges the common view that Shanghai would be the nation's largest financial center. Our findings suggest that in the Chinese context, although there are many factors affecting the formation of a financial center, the most vital locational attraction of Beijing for high-level financial firms is its value as the pivot of information 
flows and non-standardized information to reduce the problems of information externalities and asymmetry. Beijing's position as the seat of the central government also means that Beijing is the central source of political and economic information. This unique locational characteristic, hard to be copied by other cities in China, underpins Beijing's strength as a national financial center. Currently, the central government has prioritized Shanghai to be the top financial center in the country. Many incentive policies are introduced to promote the financial sector there. Nonetheless, as this paper has argued, the information can play a decisive role in the fortune of a financial center. Because the central source of non-standardized information would not be easily amenable to simply policy measures, it is questionable whether and to what extent Shanghai can replace Beijing as the national number one financial center. Although Shanghai is often viewed as the strongest candidate for being China's top financial center, our assessment tends towards Beijing based on hard statistical data as well as executive opinion survey of MNC headquarters location.

As Shanghai has achieved remarkable social and economic transformation in the past decade, a question whether and when Shanghai will replace Hong Kong as China's or even Asia's financial center is often posted in the media. However, an international financial center is developed from a national financial center. Not only many studies have argued that Shanghai is still way behind Hong Kong (Yeung, 2001), the findings in this paper also conclude that Shanghai has currently not out-competed Beijing. It can be speculated that until China completely liberalizes its political and economic systems and becomes fully transparent in business operation by international standards, Shanghai would catch up to Beijing's financial status. With full marketization, the government would be totally divorced from businesses. In the financial market, the true corporate control would replace the existing governmental control. All central regulatory bodies, such as Securities Regulatory Commission, Insurance Regulatory Commission, and Bank Regulatory Commission would become truly independent and act truly according to the market. Under this circumstance, the 
information asymmetry would be by and large minimized and become insignificant. If so, a tale of Beijing and Shanghai would resemble one of Washington and New York. However, it will have a long wait to wholly reform China's political and economic systems. In such long transformation process, Beijing could take its innate advantage of information externalities and asymmetry. Such advantage could create cumulative causation effects and make Beijing be the most important national financial service hub long before the Chinese system could be thoroughly reformed. If this would be the most likely scenario, we could further predict that Beijing would become China's "strategic control” center - the strategic and global urban center filled with MNC headquarters and the high-end/top-ranked financial and service functions. Shanghai would be China’s largest global "operational center” that fills with MNC operational offices, branches and also high-end but secondary-ranked financial and service functions. However, a full exploration of this scenario is beyond the scope of this paper and is something one can pursue in other research projects.

This study enriches the theorization of geography of finance in identifying the key factors that determine the spatial development of financial service centers in the age of information. With the sophistication of information technologies, a distance barrier to the spatial distribution of economic activities becomes less significant in the sense that standardized information can be obtained over greater distances without much cost. Banking can be done without border. But it does not mean that social contacts and the spatial proximity to "control bodies" or sources of information are no longer necessary. The profitability of certain kinds of business, like financial business, depends much upon high quality of information. In the existence of asymmetric information, however, high costs may be incurred for the information users in the attempt to collect, verify, and value-add on the information, hence requiring spatial proximity to where the flows of information, particularly the information externalities and asymmetry, are the strongest. 


\section{Reference}

Berry, B.J.L.; Conkling E.C.; and Ray, D.M. (1997). The Global Economy in Transition (second edition). Prentice Hall.

Cairncross, F. (1997). The death of distance: how the communications revolution will change our lives. Orion Business Books.

Castells, M. (1989). The Informational City. Oxford: Blackwell.

Clark, G. (1999). “ The Retreat of the State and the Rise of Pension Fund Capitalism”, in Ron (ed) Money and the space economy, Chichester: John Wiley \& Sons

Daly, M.T. (1984). The revolution in international capital markets: urban growth and Australian cities. Environment and Planning A, vol.16, pp.1003-1020.

Dicken, Peter (1998). Global Shift: Transforming the World Economy(3 ${ }^{\text {rd }}$ edition). Guilford Press.

Dunning, J.H. (1998). Location and the Multinational Enterprises: a Neglected Factor? Journal of International Business Studies, vol.29, no.1, pp.45-66.

Kerr, D. (1965). Some aspects of the geography of finance in Canada. Canadian Geographer, vol.6, no.4, pp.175-192.

Kobrin, S.J. (1997). Electronic Cash and the End of National Markets. Foreign Policy, Summer, pp.65-77.

Krugman, Paul (1991). The Geography of Trade. MIT Press.

Leyshon, A (1995), ' Geographies of money and finance I', Progress in Human Geography, vol 19, pp.531-543.

Leyshon, A (1997), ' Geographies of money and finance II’, Progress in Human Geography, vol 21, pp.381-392.

Martin, R.L. (1994). Stateless monies, global financial integration and national autonomy: the end of geography? In Corbridge, S., R.L. Martin and N. Thrift (eds.), Money, power and space. Blackwell, pp.253-278.

Martin, R.L. (1999). The New Economic Geography of Money. In R. Martin (ed.), Money and the Space Economy, John Wiley \& Sons, pp.3-27.

Ministry of Foreign Trades and Economic Cooperation (2002). Compilation of the legal instruments on China's accession to the World Trade Organization. Beijing: Law Press.

O’Brien, R. (1992). Global Financial Integration: the End of Geography. Royal Institute of International Affairs, London. 
Ohmae, K. (1990). A World Without Borders. Harper Business, NYC.

Ohmae, K. (ed.) (1995a). The Evolving Global Economy. Harvard Business Review Books, Cambridge, MASS.

Ohmae, K. (1995b). The End of the Nation-State: The Rise of Regional Economies. Harper Collins, London.

Porteous, D.J. (1995). The Geography of Finance: Spatial Dimensions of Intermediary Behaviour. Avebury.

Park, Yoon S. and Musa Essayyad (eds.) (1989). International banking and financial centers. Kluwer Academic Publishers.

Scott, A., Agnew, J., Sojia, E. \& Storper, M. (2001). Global City Regions, in Scott (ed) Global City-Regions-Trends, Theory, Policy, New York: Oxford University press

Sassen, S.(1991). The global city: New York, London, Tokyo, Princeton NJ: Princeton University Press

Sassen, S.(2001). The global city: New York, London, Tokyo, Princeton NJ: Princeton University Press

Sassen, S.(1995). On Concentration and Centrality in the Global City. In Paul L. Knox and Peter L. Taylor (eds.). World Cities in a World System. Cambridge University Press, pp. 63-75.

Short, J.R. and Yeoung-Hyun Kim (1999). Globalization and the City. Addison Wesley Longman Limited.

Thrift, N. (1994). On the social and cultural determinants of international financial centres: the case of the City of London. In Corbridge, S., Martin, R L. and Thrift, N. (eds.) (1994). Money, Power and Space. Blackwell, pp.327-355.

Yeung, Y. (2001). A tale of three cities: the competitiveness of Hong Kong, Shanghai and Singapore in the era of globalization. Occasional Paper No.1, Hong Kong Institute of Asia-Pacific Studies. 